\title{
Беларуская дэлегацыя ў Петраградзе: першая спроба «арганізаваць Беларусь» (красавік 1917 года)
}

\section{Delegacja białoruska w Piotrogrodzie: pierwsza próba „zorganizować Białoruś” (kwiecień 1917 roku)}

Rewolucja rosyjska i upadek dynastii Romanowów przyczyniły się do ożywienia ruchów narodowych w byłym imperium. 25-27 marca 1917 roku w Mińsku odbył się Kongres Białoruskich Partii i Organizacji, na którym powołano Białoruski Komitet Narodowy pod przewodnictwem Romana Skirmunta (1868-1939). Jego głównym zadaniem było zorganizowanie białoruskiego ruchu narodowego i uzyskanie autonomii Białorusi w ramach federacyjnej i demokratycznej Rosji. Wszakże wizyta delegacji białoruskiej w Piotrogrodzie w kwietniu 1917 roku i negocjacje z Rządem Tymczasowym zakończyły się niepowodzeniem. Rząd Tymczasowy nadal uważał Białoruś za „Kraj Północno-Zachodni" Rosji. Jedynym sposobem, by zmienić sytuację Białorusinów, był masowy ruch narodowy i utworzenie własnych sił zbrojnych. Jednak wiosną 1917 roku Białorusini nie posiadali ani jednego, ani drugiego.

Słowa kluczowe: rewolucja rosyjska, Białoruski Komitet Narodowy, Roman Skirmunt, Rząd Tymczasowy w Rosji, autonomia Białorusi

Пачатак рэвалюцыі 1917 года ў Расіі і крах дынастыі Раманавых паспрыялі актывізацыі беларускага нацыянальнага руху. На нейкі час Расія нават ва ўмовах вайны стала адной з найбольш свабодных 
краін Еўропы. Здавалася, зніклі ўсе перашкоды для развіцця нацыянальных культур і нацыянальнага самавызначэння народаў былой імперыі. Хваля рэвалюцыі ператварыла мінскі аддзел Беларускага таварыства помачы ахвярам вайны ў кіруючы цэнтр нацыянальнага руху. Гэтаму моцна паспрыяла тое, што ў студзені 1917 года арганізацыю ўзначаліў Раман Аляксандравіч Скірмунт (1868-1918), землеўласнік і прадпрымальнік, ідэолаг краёвага руху, былы дэпутат Дзяржаўнай думы Расійскай імперыі і фактычны ўпаўнаважаны Асобай нарады па харчовай справе, які адказваў за харчовае забеспячэнне Мінска і Мінскай губерні.

Менавіта па ініцыятыве Р. Скірмунта беларуская дабрачынная арганізацыя ператварылася ў «Беларускі камітэт», які першым выказаў ідэю аўтаноміі Беларусі ў межах дэмакратычнай федэратыўнай Расіі і пачаў падрыхтоўку з'езда беларускіх партый і арганізацый. Р. Скірмунт адразу паказаў сябе прыхільнікам кансалідацыі ўсіх беларускіх палітычных сіл. Менавіта дзеля гэтага і задумваўся з'езд.

3'езд адбыўся ў Мінску 25-26 сакавіка 1917 года і засведчыў рэдкае для беларускага руху яднанне розных палітычных сіл вакол ідэі аўтаноміі Беларусі. Таксама з'езд сфарміраваў Беларускі нацыянальны камітэт (БНК), асноўнымі задачамі якога абвяшчаліся «арганізацыя Беларусі» ў кантакце з Часовым урадам, падрыхтоўка выбараў у Беларускую краёвую раду і прапаганда выбараў ва Устаноўчы сход на прынцыпах федэратыўнай і дэмакратычнай Расійскай Рэспублікі. Дзеля вырашэння гэтых задач планавалася стварэнне губернскіх, павятовых і нават валасных аддзелаў БНК.

У склад БНК былі абраны Раман Скірмунт, Аркадзь Смоліч, Павел Аляксюк, Лявон Заяц, Эдвард Будзька, Усевалад Фальскі, Браніслаў Тарашкевіч, ксёндз Вінцэнт Гадлеўскі, Яўсей Канчар, Іван Краскоўскі, Алесь Бурбіс, Казімір Кастравіцкі, Бабарыкін, Фабіян Шантыр, Міхаіл Кахановіч, Вацлаў Іваноўскі, Лявон Дубейкаўскі і Зміцер Жылуновіч. Большасць сяброў БНК належала да Беларускай сацыялістычнай грамады (БСГ). Аднак старшынёю БНК пасля доўгіх і вострых спрэчак быў абраны Р. Скірмунт. 
Ксёндз В. Гадлеўскі пазней тлумачыў, што ў той момант ніхто з сяброў БНК, а магчыма і ўдзельнікаў з'езда не думаў пра далейшае хуткае развіццё рэвалюцыі аж «да камунізму». Урад князя Г. Львова выглядаў даволі трывалым, і перамагло меркаванне, што 3 кадэтамі лягчэй будзе весці размову якраз Р. Скірмунту, а не беларускім сацыялістам ${ }^{1}$.

У прэзідыум БНК апрача Р. Скірмунта абралі П. Алексюка і У. Фальскага як «таварышаў» старшыні, а таксама Л. Зайца (скарбнік) і Б. Тарашкевіча (пісар). Таксама з'езд вызначыў склад беларускай дэлегацыі ў Петраград. Апрача Р. Скірмунта, у яе былі абраны І. Краскоўскі, Э. Будзька, Я. Канчар, П. Аляксюк, М. Кахановіч і I. Касяк. Таксама з'езд выказаўся за «прылучэньне» да дэлегацыі прадстаўнікоў праваслаўнага і каталіцкага духавенства².

Пад канец работы з'езда па прапанове П. Алексюка была прынята дэкларацыя, якую дэлегацыя павінна была ўручыць Часоваму ўраду: «3’езд прэдстаўнікоў беларускіх палітычных партый і клясоў, сабраўшыся ў Мінску 25-27 марца гэтаго году, вітаючы вялікую расейскую рэвалюцыю, прынесшую нам свабоду і блізкасьць аўтономіі Беларусі, выражаючы сваю гатоўнасьць падтрымаць Часовы Урад у яго барацьбе з унешнімі ворагамі за свабоду Расеі і яе народаў і з прыслужнікамі старога ўраду - перэдае споўніцельную ўладу Беларускаму Нацыанальному Камітэту, каторы павінен у кантакце 3 Часовым Расейскім Урадам арганізаваць Беларусь. Беларускі Нацыанальны з'езд, умацаваны ў шчырым жаданьні нясьці часьць вялікай працы на карысьць вольных народаў Расеі, моцна перэконаны, што яго Нацыанальны Камітэт, кіруючыся да паляпшэньня жыцьця ў родным краю, прынясе карысьць агульна-гасударственнаму будаваньню на фундамэнце фэдэратыўнаго строю дэмокра-

${ }^{1}$ В. Гадлеўскі, Зь беларускага палітычнага жыцьция у Менску, «Спадчына» 1997, № 5, c. 21-22.

2 Пратакол з'езду беларускіх нацыьанальных арганізацый у Мінску 25-27 марияа 1917 г., «Спадчына» 1990, № 4, с. 33. 
тычно-рэспубліканскай Расеі, аб чым з'езд даручае сваёй дэлегацыі данясьці да ведама Часовага Ураду»³.

Такім чынам, у канцы сакавіка 1917 года з’езд беларускіх арганізацый і БНК заявілі пра гатоўнасць забяспечыць утварэнне Беларусі як аўтаномнай палітычнай адзінкі ў складзе расійскай федэрацыі. Ва ўмовах рэвалюцыйнай эйфарыі і веры ў добрую волю новых кіраўнікоў «свабоднай Расіі» гэтая задача здавалася цалкам вырашальнай. Аднак красавіцкі візіт дэлегацыі БНК у Петраград і перагаворы $з$ прадстаўнікамі Часовага ўрада паказалі эфемернасць беларускіх спадзяванняў.

Як заўважыў гісторык Станіслаў Рудовіч, у тагачасных умовах БНК было надзвычай складана стаць зародкам агульнакраёвай улады ў Беларусі. Ён мог быць толькі грамадскай установай, каардынацыйным цэнтрам, вакол якога адбывалася палітычная і нацыянальна-культурная кансалідацыя той часткі беларусаў, што заставаліся пад юрысдыкцыяй Расіi ${ }^{4}$.

Гэтаму цэнтру трэба было як мага хутчэй зразумець рэальную сітуацыю новай расійскай дзяржавы, дзе выразна дамінавалі цэнтралісцкія тэндэнцыі, якія мелі моцных саюзнікаў у Беларусі. Апрача таго, у Беларусі і побач з ёй разгортваліся нацыянальныя рухі суседніх народаў, інтарэсы якіх таксама трэба было ўлічваць у справе «арганізацыі Беларусі». А яшчэ важна было дакладна акрэсліць тыя сілы, якія гатовы былі з'яднацца вакол праграмы БНК, каб зразумець рэальнасць уласных палітычных і нацыянальных прэтэнзій.

Відавочна, што першасны склад БНК на чале з Р. Скірмунтам быў арыентаваны на кансалідацыю ўсіх наяўных беларускіх сіл, а таксама на пошук і прыцягненне патэнцыяльных саюзнікаў сярод

3 Ibidem; «Новое варшавское утро» 1917, № 2189, 29 марта; «Речь» 1917, № 74, 29 марта, с. 4.

${ }^{4}$ С. Рудовіч, Час выбару. Праблема самавызначэння Беларусі ў 1917 г., Мінск 2001, c. 92-93. 
іншых нацыянальнасцей Беларусі. Менавіта такой была пазіцыя арганізатараў з'езда і самога Р. Скірмунта. Яшчэ да сакавіцкага з'езда ён імкнуўся далучыць да беларускага руху буйных землеўласнікаў. Прыгадваючы фінансавую дапамогу з боку Мары Магдалены Радзівіл, Станіслава Радзівіла і Эдварда Вайніловіча, удзел у пасяджэннях БНК князя Г. Друцкага-Любецкага, можна сцвярджаць, што гэтыя намаганні далі пэўны пазітыўны вынік.

Выконваючы рашэнне сакавіцкага з'езда, дэлегацыя БНК у сярэдзіне красавіка адправілася ў Петраград на перагаворы з Часовым урадам па найбольш актуальных пытаннях існавання беларускай нацыі.

Напярэдадні гэтага візіту, 8 красавіка, у Петраградзе адбыўся мітынг мясцовых беларусаў. Беларусы віталі Часовы ўрад і заявілі, што апрача дэмакратычных перамен выступаюць за федэратыўны лад Расіі як неабходную ўмову яе свабоднага развіцця. Беларусь яны бачылі адным са «штатаў свабоднай федэратыўнай Расіі» ${ }^{5}$. Была прынята адпаведная дэкларацыя ў адрас Часовага ўрада. Яе падпісаў «старшыня мітынгу» Вацлаў Іваноўскі, які праз некалькі дзён далучыўся да дэлегацыі БНК.

Перад ад’ездам у Петраград БНК прыняў удзел у масавай маніфестацыі ў Мінску, што адбылася пасля заканчэння I з'езда салдацкіх і рабочых дэпутатаў Заходняга фронту, які падтрымаў палітыку Часовага ўрада. У прысутнасці такіх вядомых членаў Дзяржаўнай думы Расіi, як М. Радзянка, Ф. Родзічаў, М. Скобелеў, М. Чхеідзэ, I. Цэрэтэлі па вуліцах Мінска пад гукі «Марсельезы» прайшла калона маніфестантаў на чале з генералам А. Эвертам і яго штабам. Сярод розных нацыянальных і палітычных арганізацый ішлі таксама прадстаўнікі БНК пад белым сцягам з надпісам «Вольная Беларусь» $^{6}$. Але гэтае рэвалюцыйнае яднанне ўжо было ілюзорным.

${ }^{5}$ Государственный архив Российской Федерации (ГАРФ), ф. 1778 «Канцелярия министра-председателя Временного правительства», оп. 1, д. 244, л. 31.

${ }^{6}$ «Новое варшавское утро» 1917, № 2199, 11 апреля. 
Па прыездзе ў Петраград, яшчэ да перагавораў з Часовым урадам, беларусы сустрэліся з сябрамі Літоўскай нацыянальнай рады. Р. Скірмунт, нягледзячы на антылітоўскую пазіцыю прадстаўнікоў «заходнерускай плыні» ў беларускім руху, якую выказаў падчас сакавіцкага з'езда М. Кахановіч, усё ж не губляў надзеі на паразуменне з літоўцамі. Магчыма, што яго пазіцыя набліжалася да курсу, які ў адносінах да Літвы займалі ў той час лідары віленскіх беларусаў браты Іван і Антон Луцкевічы, Вацлаў Ластоўскі. Так, у сакавіку 1917 года А. Луцкевіч у спецыяльным мемарандуме, дасланым канцлеру Германіi, сфармуляваў галоўную мэту беларускага руху: «стварэнне з трох аб'яднаных абласией Беларусі, Літвы i Курляндыi, занятых нямецкімі войскамі, незалежнай дзяржайнай арганізащыыi» ${ }^{7}$. Сталіцай гэтай канфедэрацыі бачылася Вільня.

Для беларусаў і часткі літоўскіх і беларускіх палякаў краёвая ідэя яшчэ захоўвала сваю актуальнасць, адпаведна, прывабным выглядаў палітычны саюз з літоўскім рухам.

У Петраградзе адбылася свайго роду беларуска-літоўская канферэнцыя, дзе беларускі бок быў прадстаўлены дэлегацыяй БНК і прадстаўнікамі Беларускага камітэта ў Петраградзе. Паводле інфармацыі М. Кахановіча ${ }^{8}$, літоўцам прапанавалі саюз дзеля «лепшай будучыні для абодвух народаў». На думку беларускага боку, гэтая сувязь павінна была грунтавацца на «даўнейшай супольнай лучнасці ў форме дзяржавы - гістарычнай Літвы» а таксама на існуючай «адміністрацыйнай супольнасці» ў форме г. зв. Паўночна-Заходняга краю і адзінстве эканамічных і палітычных інтарэсаў Літвы і Беларусі ${ }^{9}$. 3 гэтымі прапановамі выступіў якраз Р. Скірмунт.

Сябар дэлегацыі ксёндз Вінцэнт Гадлеўскі пазней прыгадваў, што беларусы, апрача факта гістарычнага адзінства, казалі пра магчымасці супольнай абароны ад мацнейшых суседзяў і адзначалі

\footnotetext{
${ }^{7}$ Lietuvos mokslų akademijos Vrublevskių biblioteka, f. 21, vnt. 277, p. 12.

8 «Могилевский вестник» 1917, № 89, 20 апреля.

${ }^{9}$ Slawucič W., Biełarusy i litoŭcy ŭ 1917 hodzie, „Krynica” 1925, 18 studzienia.
} 
агульнасць палітычных і сацыяльных інтарэсаў. Між іншым, ішла гаворка пра важнасць для беларусаў выхаду да Балтыйскага мора, а для літоўцаў з' яўлення вялікага «заплечча» (Hinterland) ${ }^{10}$.

Аднак гэтая прапанова не была прынята. Літоўскія прадстаўнікі заявілі, што «літоўская справа» уужо мае міжнародны характар, a «беларускае пытанне» застаецца толькі ўнутрырасійскай праблемай. Аднаўленне Вялікага Княства Літоўскага ў форме беларуска-літоўскай федэрацыі не ўваходзіла ў іх планы.

Літоўскі рух мэтанакіравана імкнуўся да дзяржаўнасці ў межах «этнаграфічнай Літвы з прылеглымі тэрыторыямі», і краёвая ідэя ўжо не знаходзіла падтрымкі. Сябры Літоўскай нацыянальнай рады настойвалі на аўтаноміі Літвы з літоўскай адміністрацыяй у межах Ковенскай, Сувалкаўскай і Віленскай губерань. Этнаграфічныя аргументы беларусаў яны адкідалі на карысць існуючага адміністрацыйнага падзелу. «Яблыкам нязгоды» таксама стала Вільня. У адказ на літоўскія прэтэнзіі беларусы заявілі, што Вільня - не беларускі і не літоўскі горад, але паколькі ён знаходзіцца на беларускай тэрыторыі і абкружаны беларускім насельніцтвам, то павінен належаць беларусам ${ }^{11}$.

Палітычная пазіцыя кіраўнікоў літоўскага руху не пакідала ніякіх шансаў на поспех краёвай ідэі. Менавіта «сепаратысцкія імкненні Літвы» Р. Скірмунт пазней назаве галоўнай прычынай маргіналізацыі краёвага руху ${ }^{12}$.

Відавочна, што вялікай цікавасці прыезд беларускай дэлегацы не выклікаў. Многія тагачасныя петраградскія газеты («Вестник Временного правительства», «Петербургский листок», «Новое время» і інш.) наогул не заўважылі гэтай падзеі, хоць іх старонкі

10 В. Гадлеўскі, Беларускае літвафільства, «Беларускі фронт» 1938, № 7 (паводле: «Спадчына» 1993, № 2, с. 47).

${ }^{11}$ Нацыянальны архіў Рэспублікі Беларусь (НАРБ), ф. 60п «Інстытут гісторыі партыі пры ЦК КПБ», воп. 3, спр. 171, арк. 19-21.

${ }^{12}$ R. Skirmunt, Rysy odrębności Polesia [w:] Polesie ilustrowane, red. O. Nelarda, Brześć 1923, s. 28. 
былі перапоўнены інфармацыяй пра дзейнасць і патрабаванні польскіх, украінскіх і іншых нацыянальных арганізацый. Знайшлося нават месца, каб паведаміць аб прыездзе ў Петраград дэлегацыі чукчаў, якія якраз у гэты час імкнуліся прывітаць Часовы ўрад.

Пра візіт беларускай дэлегацыі паведаміла толькі газета кадэтаў «Речь» і «Русская воля», якую выдаваў былы царскі міністр унутраных спраў А. Пратапопаў. 3 заметкі на старонках «Русской воли» чытачы маглі даведацца, што 11 красавіка ў Петраград прыбыла дэлегацыя беларусаў у складзе «былога дэпутата Дзяржаўнай думы Рамана Скірмунта, інжынера Іваноўскага, народнага настаўніка Касяка, публіцыста Будзяка» (на самай справе Э. Будзькі) і інш. Адзначалася, што дэлегаты наведаюць Часовы ўрад і выканкам Савета рабочых і сялянскіх дэпутатаў, каб прывітаць іх ад імя беларускага з'езда ${ }^{13}$.

На старонках «Речи» фігуравалі таксама іншыя сябры дэлегацы: ксёндз Гадлеўскі, свяшчэннік Разумовіч, рэдактар «Могилевского вестника» М. Кахановіч і ўпаўнаважаны Усерасійскага саюза гарадоў I. Краскоўскі. Адзначалася, што дэлегаты ўручаць пастановы беларускага з'езда Часоваму ўраду і выканкаму Савета ${ }^{14}$.

Цікава, што менавіта «Речь» у канцы сакавіка 1917 года паведаміла сваім чытачам пра з'езд беларускіх партый і арганізацый у Мінску і яго рашэнні. Ужо ў той інфармацыі падкрэслівалася імкненне БНК спрыяць «развитию России на принципах федеративного, демократически-республиканского строя» ${ }^{15}$.

Гэтыя сціплыя газетныя паведамленні дазваляюць удакладніць склад беларускай дэлегацыі. Можна меркаваць, што згодна 3 пажаданнямі ўдзельнікаў з'езда яна была дапоўнена прадстаўнікамі каталіцкага (В. Гадлеўскі) і праваслаўнага (Разумовіч) духавенства.

13 «Русская воля» 1917, № 58, 12 апреля; НАРБ, ф. 60п, воп. 3, спр. 175, арк. 16.

\footnotetext{
14 «Речь» 1917, № 84, 12 апреля; НАРБ, ф. 60п, воп. 3, спр. 175, арк. 17.

15 «Речь» 1917, № 74, 29 марта.
} 
Таксама фігуруе імя В. Іваноўскага, які, магчыма, замяніў Я. Канчара.

Я. Канчар на старонках мінскай газеты «Новое варшавское утро» пасля публікацыі заметкі пра вяртанне беларускай дэлегацыі з Петраграда, заявіў, што выйшаў з яе складу, бо не падтрымлівае ідэю аўтаноміі Беларусі: «Як сацыяліст-народнік, я выступаю за дэмакратычную рэспубліку з мясцовым самакіраваннем на падставе нацыянальнага самавызначэння і гістарычных умоў мясцовасці. Толькі так я і разумею самакіраванне Беларусі. Федэратыўны лад у Расіі і федэратыўнае ўладкаванне Беларусі лічу непрымальным, зыходзячы 3 гісторыі стварэння рускай дзяржавы, а таксама амерыканскай і швейцарскай практыкі» ${ }^{16}$.

Яшчэ двое сяброў дэлегацыі не былі заўважаны петраградскім друкам. Між тым, імя ўрача Аляксандра Ярэміча прысутнічае ў «Дакладной запісцы», перададзенай міністру-старшыні Часовага ўрада 14 красавіка. А Павел Аляксюк расказаў аб працы дэлегацыі падчас з'езда беларускіх арганізацый у Мінску ў ліпені 1917 года.

Першы візіт дэлегацыя нанесла кіраўніку Часовага ўрада і адначасова міністру ўнутраных спраў князю Львову. Яму была ўручана падрыхтаваная загадзя «Дакладная запіска». Адпаведна, падчас размовы падкрэслівалася неабходнасць абвяшчэння Расіі федэратыўнай рэспублікай, дэмакратызацыі гарадскога і земскага самакіравання, беларусізацыі адукацыі (увядзення беларускамоўнага навучання ў сістэме народных школ, вывучэння беларускай мовы і гісторы Беларусі, а таксама беларускай літаратуры і краязнаўства ў настаўніцкіх і духоўных семінарыях і інш.). Таксама закраналася пытанне кампенсацыі тых страт, якія панесла беларускае насельніцтва падчас ваенных дзеянняў.

П. Аляксюк, успамінаючы пра гэты візіт, адзначыў, што князь Львоў «выслухаў усё гэта ўважна, але сказаў, што ўсе гэтыя

\footnotetext{
16 «Новое варшавское утро» 1917, № 3009, 23 апреля.
} 
дамаганьні належуцца да розных міністраў» ${ }^{17}$. Паводле В. Гадлеўскага, кіраўнік урада заявіў, што пажаданні беларусаў можа здаволіць толькі Устаноўчы сход ${ }^{18}$.

М. Кахановіч таксама адзначыў, што дэлегацыя звярнула ўвагу міністра-старшыні на беспадстаўнасць літоўскіх прэтэнзій на беларускія тэрыторыі ў межах Ковенскай, Сувалкаўскай і Віленскай губерань, а таксама на Вільню ${ }^{19}$. Князь Львоў заявіў, што прымае да ведама беларускі пратэст і прызнаў, што ўжо атрымаў дэкларацыю літоўцаў, у якой згадваюцца тэрыторы трох губерань. Беларуская дэлегацыя яшчэ раз заявіла пра адсутнасць падстаў для падобных прэтэнзій ${ }^{20}$.

На экзэмпляры «Дакладной запіскі», які захаваўся ў фондзе Міністэрства ўнутраных спраў Часовага ўрада ў Нацыянальным архіве Расійскай Федэрацыі, прысутнічае рэзалюцыя князя Львова, які накіраваў гэты дакумент свайму намесніку Сяргею Лявонцьеву. Змест гэтага дакумента варта прывесці цалкам ${ }^{21}$ :

Докладная записка съезда белорусских общественных организаций

25, 26 и 27 марта 1917 года в Минске состоялся Съезд Бел[орусских] Общ[ественных] Деятелей, который избрал из своей среды для проведения в жизнь постановлений съезда «Бел[орусский] Нац[иональный] Комитет».

По вопросам общеполитическим съезд высказался следующим образом: «Признавая, что основные взаимоотношения между Белоруссией и Рос[сийской] Державою должны быть определены Всероссийским Уч-

17 «Вольная Беларусь» 1917, № 8, 21 ліпеня.

183 жыцьия і дзейнасьиі кс. В. Гадлеўскага. Аўтабіяграфічны нарыс, «Беларуская крыніца» 1928, 12, 16 лютага.

19 «Могилевский вестник» 1917, № 89, 20 апреля.

${ }^{20}$ НАРБ, ф. 60п, воп. 3, спр. 171, арк. 22.

21 ГАРФ, ф. 1800 «Департамент общих дел Министерства внутренних дел Временного правительства», оп. 1, д. 44, л. 1-1 об. Тэкст «Дакладной запіскі» выклікае здзіўленне, бо больш нагадвае чарнавік, аўтар якога ўжываў скарачэнні слоў. Аднак менавіта на гэтым тэксце змешчана рэзалюцыя князя Львова. 
p[едительным] Собр[анием], съезд Б[елорусских] О[бщественных] Деятелей считает, что единственной возможной формой государственного устройства Р[оссийской] Д[ержавы] является федеративная республика. Ядром Б[елоруссии] являются губернии: Минская, Могилевская, Витебская, Гродненская и Виленская.

Ввиду отсутствия в некоторых губ[ерниях] земских организаций, а в других наличия лишь „столыпинских” упрощенных организаций самоуправления, необходимо ускорить введение в Крае учреждений городского и земского самоуправления на демократических началах».

По вопросам народного образования съезд высказался следующим образом: «Необходимо назначение в местные органы Центральных управлений по Мин[истерству] Н[ародного] П[росвещения] людей Края, предложенных местными национальными организациями. Преподавание в низших народных школах Белоруссии должно вестись на родном бел[орусском] языке. В учительские и духовные семинарии вводится изучение Белорусского языка, истории Белоруссии, Белорусской литературы и краеведения. Те же предметы вводятся факультативно и в средние школы Бел[оруссии]. Необходимо немедленное учреждение в Б[елоруссии] университета и высшего спец[иального] уч[ебного] заведения. В университете необходимо учредить кафедры белорусского языка, литературы, истории и краеведения Б[елоруссии]».

По вопросу о возмещении населению убытков, причиненных военными действиями, съезд высказался за необходимость немедленного изменения закона от 6 окт. 1916 г. для действительного обеспечения разоренному населению возможности получить возмещение убытков, причиненных военными действиями.

14 апреля 1917 г.

Председатель съезда Р. А. Скирмунт [подпіс]

Члены делегации: крестьянин Виленской губ. Будславской вол. Э. Будзько, народный учитель Виленской губ. И. Косяк, доктор медицины А. П. Еремич, уроженец Минской губ., инженер, техник, доктор технических наук В. Л. Ивановский, Виленская губ., преподаватель Могилевского ремесленного училища М. С. Каханович, юрист П. П. Алексюк, Гродненская губ.

Минск, Захарьевская, 31, Белорусский национальный комитет 
Дэлегацыя таксама наведала С. Лявонцьева, які пачаў размову 3 пытання: «Якая рэальная сіла стаіць за дэлегацыяй?» П. Аляксюк сказаў пра вялікую маральную сілу. Згадаўшы пра гэта падчас з'езда, ён прызнаў, што на чыноўніка гэтае прызнанне не зрабіла ніякага ўражання. С. Лявонцьеву таксама паскардзіліся на губернскіх камісараў з ліку гласных былога «сталыпінскага» земства, якія працягвалі «абрусіцельную палітыку». Той у адказ заявіў, што «спагадае гэтай бядзе, але памагчы нічым ні можа, ня можа ісьці проціў выбарной уласьці».

Міністр народнай асветы А. Мануйлаў таксама ўважліва выслухаў пажаданні адкрыцця ў Беларусі ўніверсітэта і сельскагаспадарчага інстытута, прыстасавання школьных праграм да асабліваасцей краю і перадачы кіравання сістэмай адукацыі ў рукі мясцовых ураджэнцаў. Міністр пагадзіўся з выказанымі прапановамі, але заявіў, што ён нічога не можа зрабіць і параіў накіраваць беларускіх прадстаўнікоў у камітэт пры Міністэрстве народнай асветы.

Паводле ўспамінаў П. Алексюка, найбольш канкрэтнай была размова 3 обер-пракурорам Сінода Уладзімірам Львовым. Той, дарэчы, падтрымліваў дэмакратычна і па-рэфарматарску настроеную частку духавенства і канфліктаў з іерархамі праваслаўнай царквы. Сябры дэлегацыі звярнулі ўвагу на палітычныя выступленні асобных высокіх прадстаўнікоў царквы ў Беларусі, якія, на іх думку, распальвалі міжнацыянальную і міжрэлігійную варожасць. Львову перадалі экзэмпляр адозвы аднаго з такіх іерархаў, і пракурор пагадзіўся, што такіх людзей нельга трымаць на пасадзе. Таксама абмяркоўвалася кандыдатура епіскапа-беларуса. Але ніякіх вынікаў гэта не мела.

Важнай падзеяй для дэлегацыі быў візіт да адміністратара Магілёўскай архідыяцэзіі і кіраўніка каталіцкага касцёла ў Расіі біскупа Яна Цепляка. 12 красавіка Р. Скірмунт, В. Гадлеўскі, Э. Будзька і П. Аляксюк уручылі біскупу заяву аб неабходнасці ўвядзення беларускай мовы ў касцёле. У заяве сцвярджалася ненармальнасць раздвоенасці беларусаў, якія ў хаце гавораць па-бе- 
ларуску, а ў касцёле па-польску. Таксама прыводзіліся прыклады ранейшых спроб увядзення беларускай мовы ў касцёле, пачынаючы 3 айцоў езуітаў у Хвашчоўцы. Беларускія дзеячы падкрэслівалі асаблівую патрэбу беларусізацыі касцельнага жыцця ў тагачаснай сітуацыі, „bo aproč narodnaha biełaruskaha ruchu, katory žadaje swaje mowy ŭ kaścieli, a także aprača karyści, jakuju prynosić nawučeńnie wiery ŭ rodnaj mowi, siudy jašče dałučajecca patrebnaść niaści światło wiery katalickaj tym, katoryja ciapier nawaročywajucca da katalickaha Kaściołu i da katorych ciažka zwaročywacca papolsku, bo jany jaje zusim nie razumiejuć, inšymi sławami, palščyna u ciapierašnich warunkach moža pryniaści tolki škodu katalickamu kaściołu na Biełarusi, a nie karyśćc"22.

У заяве выказваліся пажаданні ўвядзення лекцый беларускай мовы, літаратуры і гісторы ў Магілёўскай духоўнай семінарыі ў Петраградзе; чытання ў касцёлах зваротаў вышэйшага духавенства ў тым ліку па-беларуску; перадачы беларускаму духавенству касцёлаў, якія будуць вернуты новым урадам і ў якіх можна будзе адразу ўвесці беларускую мову; выдання беларускамоўных кніг для касцёла і школы, а таксама часопіса; прызначэння ў Беларусь ксяндзоў-беларусаў або тых, хто валодае беларускай мовай; i, нарэшце, прызначэння біскупа-беларуса або таго, „katory umieje pa-biełarusku hawaryć, znaje biełaruski narod i jaho patreby”. Таксама біскупа прасілі нагадаць духавенству ў Беларусі пра яго абавязак „nakolki chopić sił i mahčymaści pramaulać pa-biełarusku da ludziej u nawučańni wiery ŭ kaścieli i školi”".

Каталіцкі іерарх спагадліва паставіўся да беларускай дэлегацыі, але нейкіх практычных вынікаў візіт і заява не мелі.

П. Аляксюк нічога не сказаў пра наведванне выканкама Петраградскага Савета рабочых і салдацкіх дэпутатаў, але, відавочна, што і той візіт меў аналагічны вынік. Усе ўважліва слухалі, спагадалі і... нічога не рабілі. Агульны вынік працы дэлегацыі, па-

${ }^{22}$ Ab biełaruskaj mowi u kaścieli, «Homan» 1918, nr 39. 
водле П. Алексюка, можна перадаць адным словам рускай мовы: «вообще» ${ }^{23}$.

Ацэньваючы гэты візіт, варта адкінуць эмоцыі, характэрныя для маладых беларускіх палітыкаў, якія з цяжкасцю пазбываліся рэвалюцыйнай эйфарыі. Магчыма, галоўным вынікам дзейнасці беларускай дэлегацыі на чале з Р. Скірмунтам было давядзенне да ведама новага расійскага ўрада рашучага імкнення дзеячаў беларускага руху да аўтаноміі Беларусі і федэралізацыі Расіі, адстойванне нацыянальных інтарэсаў у спрэчках 3 Літоўскай нацыянальнай радай. Таксама важным момантам было наладжванне пастаяннага кантакту паміж Часовым урадам і БНК праз упаўнаважаных апошняга. Такімі паўнамоцтвамі Р. Скірмунт надзяліў Эдварда Будзьку і Аляксандра Ярэміча, пра што паведаміў намесніку міністра ўнутраных спраў Дзмітрыю Шчэпкіну ${ }^{24}$.

Фактычна, галоўным вынікам візіту беларускай дэлегацыі стала 3'яўленне «беларускага пытання» ў парадку дня ўнутрырасійскай палітыкі.

Але адначасова гэты візіт паспрыяў актывізацыі сіл, варожых беларускаму руху. Дарэчы, водгукі змагання адчуваліся нават у сталіцы Расіi. Так, газета «Речь» 13 красавіка змясціла пратэст БНК супраць тых заяў, якія рабіліся арганізатарамі I з'езда сялянскіх дэпутатаў Мінскай і Віленскай губерань ${ }^{25}$.

Ад імя БНК было заяўлена наступнае: «На белорусском национальном съездзе присутствовало до 150 человек, представители политических партий Белоруссии: Белорусской социалистической грамады, Народно-демократической беспартийной группы, Демократической католической партии и других различных групп, которые в своих декларациях и своим единогласным принятием резолюций определили характер съезда. Таким образом, это был

\footnotetext{
23 «Вольная Беларусь» 1917, № 8, 21 ліпеня.

${ }^{24}$ ГАРФ, ф. 1800, оп 1 , д. 44, л. 2.

25 «Речь» 1917, № 85, 13 апреля.
} 
не „так называемый съезд”, а действительно съезд белорусских общественных деятелей, работающих уже много лет над делом возрождения Белоруссии, среди которых было немало представителей старой краевой политической партии, имеющей свою историю и заслуги, Белорусской социалистической грамады. Правильно организованного представительства крестьян и рабочих на этом съезде, как и на съездах других организаций быть не могло, но заявление, что „белорусский народ в лице своих трудовых классов - крестьян и рабочих" в работах национального съезда никакого участия не принимал - совершенно неверно» ${ }^{26}$.

Між тым, 20-23 красавіка 1917 года ў Мінску адбыўся I з'езд сялянскіх дэпутатаў Мінскай і Віленскай губерань. Ён сабраў больш за 800 дэлегатаў і праходзіў пад старшынствам М. Фрунзэ. Як сведчыць дакладная запіска яго намесніка Піліпа Караткевіча ад 1 снежня 1917 года, галоўнай задачай арганізатараў было супрацьдзейнічаць беларускаму руху і рашэнням сакавіцкага з'езда ${ }^{27}$. На з'ездзе панавалі антыбеларускія настроі. БНК называлі «інтрыгай памешчыкаў». Дэлегаты прагаласавалі за рэзалюцыю, якая асуджала ідэю палітычнай аўтаноміі Беларусі і выказвалася за абласное самакіраванне ў межах Расійскай Рэспублікі.

Няўдача ў Петраградзе значна ўскладніла становішча Р. Скірмунта ў беларускім руху. Ужо ў другой палове красавіка 1917 года ў БНК пачала фарміравацца свайго роду «антыскірмунтаўская апазіцыя». Атмасфера на пасяджэннях пачала абвастрацца. Беларускія сацыялісты пачалі думаць пра замену кіраўніцтва. Важную ролю адыгрывала і тое, што большасць беларускіх арганізацый на месцах арыентавалася на БСГ. Адным з ініцыятараў стварэння гэтай апазіцыі быў кіраўнік Мінскага бюро БСГ і рэдактар газеты «Грамада» Аркадзь Смоліч ${ }^{28}$.

\footnotetext{
${ }^{26}$ НАРБ, ф. 60п, воп. 3, спр. 175, арк. 18.

${ }^{27}$ Ibidem, ф. 4 «Беларускі нацыянальны камісарыят», воп. 1, спр. 98, арк. 188.

${ }^{28}$ А. Ліс, Аркадзь Смоліч [у:] А. Ліс, Выюранае, Мінск 2014, с. 156.
} 
Беларускі даследчык Арсень Ліс трапна заўважыў: «Як на прадстаўнічую дэлегацыю ў Петраград да Часовага ўрада з беларускімі пастулатамі, то былы член Думы, імпазантны Скірмунт, пэўна, падыходзіў. Але штось іншае было [патрэбна, каб] дзейсна весці беларускую работу ў свеце, які імкліва радыкалізаваўся, ды ўнутры БНК, у асяроддзі маладых сацыялістаў. [...] Аб поглядах яго не пыталіся: якая каму была патрэба ведаць, што гэты памешчык даў слова безаглядна падпарадкавацца ў будучым рашэнню Устаноўчага сходу - перадаць сваю зямлю сялянам ${ }^{29}$.

Спадзяванні кіраўніцтва БНК на магчымае яднанне беларусаў на глебе нацыянальнай ідэі паступова слабелі і разбураліся. Сітуацыю, сапраўды, магла палепшыць спроба пэўнага спалучэння беларускай ідэі 3 папулярнай сацыяльнай-эканамічнай праграмай або нават падпарадкаванне гэтай ідэі вырашэнню першачарговых сацыяльных праблем, але ў тагачаснай сітуацыі гэта магло прывесці да «растварэння» беларускіх арганізацый у агульнарасійскім сацыялістычным руху, дзе дамінавалі прадстаўнікі рэвалюцыйнага цэнтралізму, і ў рэшце рэшт да фактычнай адмовы ад барацьбы за нацыянальныя каштоўнасці і дзяржаўнае самавызначэнне.

Аднак амаль ніхто ў беларускім руху ўжо не ставіў пад сумненне ідэю аўтаноміі Беларусі. Вялікая заслуга ў гэтым належала P. Скірмунту і яго прыхільнікам з ліку сяброў мінскага аддзела Беларускага таварыства помачы ахвярам вайны. На аснове пастулата аб аўтаноміі паступова ўмацоўвалася ідэя незалежнасці Беларусі, якая на ўвесь голас заявіла пра сябе 25 сакавіка 1918 года.

Архіўныя крыніцы

Lietuvos mokslų akademijos Vrublevskių biblioteka, f. 21, vnt. 277, p. 12.

Государственный архив Российской Федерации, ф. 1778 «Канцелярия министра-председателя Временного правительства», оп. 1, д. 244, л. 31; ф. 1800 «Департамент общих дел Министерства внутренних дел Временного правительства», оп 1, д. 44, л. 1-2.

${ }^{29}$ A. Лic, Gloria victis! Збор твораў, Мінск 2010, с. 89. 
Нацыянальны архіў Рэспублікі Беларусь, ф. 4 «Беларускі нацыянальны камісарыят», воп. 1, спр. 98, арк. 188; ф. 60п «Інстытут гісторыі партыі пры ЦК КПБ», воп. 3, спр. 171, арк. 19-22; спр. 175, арк. 16-18.

\section{Літаратура}

Ab biełaruskaj mowi u kaścieli, „Homan” 1918, nr 39.

Skirmunt R., Rysy odrębności Polesia [w:] Polesie ilustrowane, red. O. Nelarda, Brześć 1923.

Slawucič W., Biełarusy i litoŭcy ŭ 1917 hodzie, „Krynica” 1925, 18 studzienia. «Вольная Беларусь» 1917, № 8, 21 ліпеня.

Гадлеўскі В., Беларускае літвафільства, «Беларускі фронт» 1938, № 7 (паводле: «Спадчына» 1993, № 2).

Гадлеўскі В., Зь беларускага палітычнага жыцьия у Менску, «Спадчына» 1997, № 5.

3 жыцьия $i$ дзейнасьиі кс. В. Гадлейскага. Аўтабіяграфічны нарыс, «Беларуская крыніца» 1928, 12, 16 лютага.

Лic A., Gloria victis! Збор твораў, Мінск 2010.

Ліс А., Аркадзь Смоліч [у:] Ліс А., Выбранае, Мінск 2014.

«Могилевский вестник» 1917, № 89, 20 апреля.

«Новое варшавское утро» 1917, № 2189, 29 марта; № 2199, 11 апреля; № 3009, 23 апреля.

«Речь» 1917, № 74, 29 марта; № 84, 12 апреля; № 85, 13 апреля.

Пратакол з'езду беларускіх нацыанальных арганізацый у Мінску 25-27 мариа 1917 г., «Спадчына» 1990, № 4.

Рудовіч С., Час выбару. Праблема самавызначэння Беларусі у 1917 г., Мінск 2001.

«Русская воля» 1917, № 58, 12 апреля.

\section{Belarusian delegation to the Petrograd: The first attempt to "organize Belarus" (April, 1917)}

The Russian Revolution and the fall of the Romanov dynasty contributed to the revitalization of the national movements in the former empire. In the March 25-27, 1917 in Minsk the Belarusian Congress of Parties and Organizations on which the Belarusian National Committee, headed by Roman Skirmunt (1868-1939) was created. Its main 
task was to organize the mass of the Belarusian national movement and to achieve the autonomy of the Belarus within the framework of a federal and democratic Russia. However, the visit of the Belarusian delegation to Petrograd in April, 1917 and the negotiations with the Provisional Government was failed. The interim government is still regarded Belarus as the "North-West territory" of the Russia. The only argument that could change its position, was massive national movement in Belarus and the creation of its own military forces. However, in the spring of 1917 Belarusians had no such an argument.

Key w o r d s: Revolution in Russia, the Belarusian National Committee, Roman Skirmunt, the Provisional Government in Russia, Belarus autonomy 